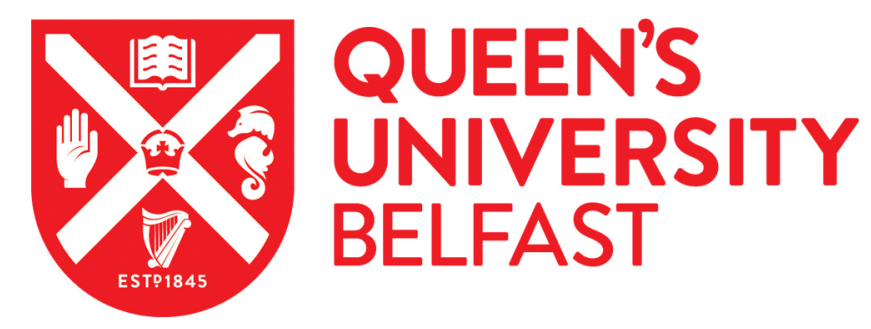

\title{
Civilianizing Civil Conflict: Civilian Defense Militias and the Logic of Violence in Intra-State Conflict
}

Clayton, G., \& Thomson, A. (2016). Civilianizing Civil Conflict: Civilian Defense Militias and the Logic of Violence in Intra-State Conflict. International Studies Quarterly, 60(3), 499-510. https://doi.org/10.1093/isq/sqv011

Published in:

International Studies Quarterly

Document Version:

Peer reviewed version

Queen's University Belfast - Research Portal:

Link to publication record in Queen's University Belfast Research Portal

Publisher rights

(C) 2015 The Authors

\section{General rights}

Copyright for the publications made accessible via the Queen's University Belfast Research Portal is retained by the author(s) and / or other copyright owners and it is a condition of accessing these publications that users recognise and abide by the legal requirements associated with these rights.

Take down policy

The Research Portal is Queen's institutional repository that provides access to Queen's research output. Every effort has been made to ensure that content in the Research Portal does not infringe any person's rights, or applicable UK laws. If you discover content in the Research Portal that you believe breaches copyright or violates any law, please contact openaccess@qub.ac.uk. 


\begin{abstract}
This article examines how civilian defense militias shape violence during civil war. We define civilian defense forces as a sedentary and defensive form of pro-government militia that incumbents often use to harness the participation of civilians during a counterinsurgency campaign. We argue that civilian defense forces reduce the problem of insurgent identification. This leads to a reduction in state violence against civilians. However, we also claim that these actors undermine civilian support for insurgents, which leads to an increase in rebel violence against civilians and overall intensification of conflict. A statistical analysis of government and rebel violence against civilians from 1981 to 2005, and a qualitative assessment of a civilian defense force operating in Iraq from 2005 to 2009, offer strong support for our theoretical claims. These findings provide further insight into pro-government militias and their effects on violence. They also have wider ethical implications for the use of civilian collaborators during civil war.
\end{abstract}

Key Words: Pro-Government Militias, Civilian Defense Forces, Counterinsurgency, Civil War, Conflict Intensity, One-Sided Violence, Violence against Civilians. 
When officials delegate security and counterinsurgency to civilian militias, how does this influence violence in civil wars? Between 2005 and 2009, Coalition forces in Iraq recruited Sunni tribal members to undertake security and combat operations. The "Sons of Iraq” militia program helped the Coalition defend local communities from insurgents; they played a pivotal role in the stabilization of Iraq (Biddle, Friedman, and Shapiro 2012:19-20; Smith and Macfarland 2008:42-48). The "Sons" provide an example of a civilian defense force, which are a unique form of pro-government militia. These civilian defense forces are composed mainly of civilians who undertake intelligence and limited combat roles to extirpate insurgents from their community. In comparison, other militias are often more mobile, composed of a wider range of recruits — such as ex-servicemen, criminals, and conscripts, They undertake a variety of different roles, including offensive operations, election agitation, and private security. Between 1981 and 2007, almost a quarter of the 83 states that mobilized a pro-government militia delegated some responsibility to a civilian defense force. From Iraq to Colombia and from Angola to the Philippines, civilian defense forces are a regular feature of civil war. However, despite the frequency with which they operate, scholars lack a sufficient understanding of how civilian militias affect civil violence.

We argue that since civilian defense forces contain members of the local population, they possess unique knowledge of the people within the communities in which insurgents and their sympathizers hide. This local knowledge allows the militias and their state patron to more effectively and selectively target insurgents. However, using civilians to identify insurgents provokes a response from the rebels; rebels retaliate-and target the local population-to deter future defections and re-establish control. This drives a wedge between insurgents and the local population, increasing rebel violence against civilians. More effective incumbent 
targeting, increased rebel violence against civilians, and insurgent fragmentation triggered by the increasingly hostile environment lead to more deadly civil wars.

We test our arguments with a nested mixed-method research design (Lieberman 2005). We use a negative binomial regression model to analyze recently released data coding the presence of all militias operating globally between 1981 and 2005, as well as counts of civilian fatalities undertaken by rebel and government forces. Following Lieberman’s “model testing” small-N approach, we then offer a case analysis of civilian forces in Iraq. We use this case to clarify our method of conceptualization and more convincingly rule out rival explanations (Lieberman 2005:440-442). The combined results strongly support our claims.

We offer important conceptual and empirical contributions to the growing collection of work centered on the effects of pro-government militias (Carey, Colaresi, and Mitchell 2015; Jentzsch, Kalyvas, and Schubiger 2015; Mitchell, Carey, and Butler 2014; Schubiger 2012; Stanton 2015). While most studies tend to examine state delegation of violence as a means to avoid accountability, we make broader claims about patterns of civil war violence. In so doing, we provide a contribution to emerging debates on insurgent defection, sideswitching, and splintering (e.g. Bakke, Cunningham, and Seymour 2012; Cunningham 2013, 2014; Staniland 2012, 2014). By highlighting the role of civilian collaborators in the maintenance of political order, we also speak to ongoing debates concerning the use of social networks in imperial conquest (e.g. Macdonald 2014), as well as developing states' governance strategies (e.g. Ahram 2011; Belge 2011; Holden 2004; Thomson 1994; Tilly 2003). We show that while actors commonly use civilians as a source of information on insurgents, this leads to increased insurgent targeting of civilians and more deadly civil conflicts. 
From a policy-making perspective, this presents significant ethical issues for those considering implementing such divisive strategies. Supporting civilian militias increases incumbents' ability to identify insurgents and establish control, but such incumbents should take steps to protect civilian groups in order to offset the pernicious effects of placing them at the center of armed conflict.

\section{The Effects of Pro-Government Militias}

Pro-government militias are organized armed groups that are aligned with the government—at the national or subnational level—but not identified as members of the conventional armed force (Carey, Mitchell, and Lowe 2013:250). Most studies on the effects of militias focus on the relationship between pro-government militias and human rights violations. Informal militias (i.e. those not officially linked to the state) provide incumbents a means to off-load "dirty work" and plausibly deny extreme methods used to target opponents and civilians (Campbell 2002:13-14; Cohen and Nordas 2015). Unofficial militia groups are therefore strongly associated with human rights abuses and civilian targeting (Carey, Colaresi, and Mitchell 2015; Mitchell, Carey, and Butler, 2014:818-819; Raleigh 2012:463-464).

Previous research reveals how militias support weak state institutions (e.g. Ahram 2011:15-19; Klare 2004:120-121). Militias offer incumbents governing weak institutional structures a cheaper method to engage insurgents (Carey, Colaresi, and Mitchell 2011:6-7). In this way, a state's creation and/or collaboration with militias provides a non-traditional means of consolidating power (Ahram 2011:14-15). However, weak states often lack the ability to control militia violence (Barter 2013:20; Mitchell, Carey, and Butler 2014:813-817). Therefore, rather than violence occurring because states are unwilling to control militias, 
violence can also occur when the state is unable to exert sufficient control over a group (Mitchell 2004:46-50).

Finally, a third body of literature discusses the role that militias can play in assisting incumbents to overcome the "identification problem" (Kalyvas 2006:108-109; Lyall 2010:15). This problem arises from the challenges of identifying insurgents within a civilian population (Galula 1964:55-57; Kalyvas 2006:89-91; Kilcullen 2010:10-31). In the absence of reliable intelligence, incumbents must choose between inaction and the adoption of indiscriminate forms of violence (Kalyvas 2006:147-149). Given the obvious problems associated with inaction, a lack of reliable intelligence more commonly leads to indiscriminate violence. This approach often proves counterproductive. It alienates the very people the incumbent is attempting to win over to their side (Downes 2008:2-9). Research suggests that militias can provide local information on insurgents that allows the state to apply violence more selectively (Kalyvas 2006:107; McClintock 1992:251-252; Peic 2014; Jones 2012:1517).

\section{Types of Pro-Government Militias}

Despite highlighting key effects produced by pro-government militias, existing accounts fail to adequately distinguish between different types of militias and the unique roles they may perform. A lack of cross-national data generally prevents the effective categorization of militia forces, and limits analysis of the effects associated with different forms of militia groups. However, Carey, Mitchell, and Lowe (2013:251-253) distinguish between militias in relation to their link with the state. They categorize groups as either "informal" or "semiofficial.” Mitchell, Carey, and Butler (2014) draw on this typology, adopting a principal-agent 
framework to argue that groups informally linked to the state have a stronger negative effect on human rights violations.

However useful the informal/semi-official distinction, it does not help account for how differences in a variety of factors—-such as the recruitment base and mode of operation—can impact conflict processes. Examination of a broader range of factors, such as their relationship with rebel organizations (Barter 2013), will enable a deeper understanding of the effects of militias. For instance, it remains unclear why militias prove better than conventional incumbent forces at separating insurgents from civilians. The membership composition and operational parameters of militias often differ little from those of state forces (Carey, Mitchell, and Lowe 2013:251-253). Some groups comprise off-duty military or police, which should offer no distinct advantage for gaining information. Recent literature makes some in-roads in discussing pro-government militia heterogeneity, but still fails to delineate the varied nature of these actors and their impact on civil-war dynamics (Ahram 2014; Barter 2013; Carey, Mitchell, and Lowe 2013). This article contributes towards a better understanding of the impact of pro-government militias on civil-war dynamics by focusing on the effects of one particular sub-set of militias: civilian defense forces.

\section{Civilian Defense Forces}

Many counterinsurgent thinkers identify civilian defense forces as a type of progovernment militia (Galula 1964:82-94; Jones 2013:15; Mclintock 1992:247-249). Civil war scholars also increasingly recognize them (Barter 2013; Fumerton and Remijnse 2004; Peic 2014). To add to this literature, we highlight a number of criteria that define civilian defense forces. Firstly, they are recruited mainly from civilian populations. Unlike non-civilian defense forces that comprise off-duty policemen/military, ex-servicemen, or other conscripts with some 
level of military training, civilian defense forces recruit civilian groups from within areas contested by the incumbent and insurgent forces. Secondly, civilian defense forces remain within their recruitment areas. Unlike mobile fighting forces that cross from one area to the next, they are static. Along with their civilian status, this means that civilian defense force members typically live in their own homes rather than reporting to a barracks. Thirdly, civilian defense forces perform “defensive” tasks. They undertake intelligence, security, and limited combat roles concerned with the protection of their local areas from insurgents. They extirpate insurgents from their own communities and deny access to insurgents from the outside. We differentiate civilian defense forces from militias that actively target a variety of opponents across wide areas. We also differentiate them from groups who perform other roles within their local community that are not connected to an insurgency.

In sum, civilian defense forces are pro-government militia that harnesses the active participation of civilians, and defected members of an insurgency, in sedentary, defensive counterinsurgent roles. We contrast civilian defense forces from “death squad”-style militias. These include military-trained personnel that operate according to military-style command structures. They also roam large areas in active search of insurgents or other opponents, such as “death squads” in Latin American during the Cold War (see Table I) (Mazzei 2009:4-10). We also conceptually contrast civilian defense forces from local vigilante police. Civilian defense forces defend their community from insurgents, unlike vigilante police that identify common criminals and cattle thieves or enforce specific legal codes, such as sharia law. Civilian defense forces are a historically common feature in irregular wars, from "civil defense patrols” in Peru and Guatemala to Turkish Village Guards and to Filipino Citizen Armed Force Geographical Units. 
Non-civilian defense forces do not represent a single category as they vary considerably in their composition, operational parameters, and context. The multiple sub-categories of noncivilian defense forces, however, are beyond the scope of this article. Non-civilian defense forces operate in a variety of contexts with diverse operational parameters, ranging from personal guards, to security forces operating in non-civil war settings. For example, the "Xinjiang Production and Construction Corps” protected business interests in China and the "White Eagles" in Serbia—a militarily organized state-led group— conducted various attacks during the dissolution of former Yugoslavia (Mitchell, Carey, and Lowe 2013). In other words, while civilian defense forces exhibit particular characteristics in a counterinsurgent context, the non-civilian defense force category captures a variety of pro-government militias.

Table I: Civilian Defense Forces vs. Non-Civilian Defense Forces

\begin{tabular}{|l|l|l|}
\hline & $\begin{array}{l}\text { Civilian Defense } \\
\text { Forces }\end{array}$ & Non-Civilian Defense Forces \\
\hline Participants & Civilians & $\begin{array}{l}\text { - Any } \\
\text { - Often ex-military conscripts, off-duty personnel, } \\
\text { mercenaries and foreign fighters. }\end{array}$ \\
\hline Area of operation & $\begin{array}{l}\text { Local (area of } \\
\text { recruitment) }\end{array}$ & $\begin{array}{l}\text { - No primary geographic focus } \\
\text {-Often mobile operating across large territories }\end{array}$ \\
\hline $\begin{array}{l}\text { Parameter of } \\
\text { operations }\end{array}$ & $\begin{array}{l}\text { Defensive - i.e. non- } \\
\text { active }\end{array}$ & - Any operate locally \\
\hline
\end{tabular}

\section{Overcoming the Problem of Identification}

Members of local communities generally know who individual insurgents are, or at least which residents are likely to hide them. Militias that comprise local residents and 
insurgent defectors are best placed to identify insurgents (Kalyvas 2006:107; Lyall 2010:1-4). Other types of militia, such as mobile informal groups, operate away from their villages of origin and are not privy inside information. Civilian defense forces have a unique ability to reduce the identification problem. We see this as part of a wider effort on behalf of states to make their citizenry "legible" (Belge 2011). In addition to this intelligence function, leveraging civilian defense forces is a political tool to increase civilian support for the incumbent.

The formation of civilian defense forces is likely to fundamentally alter state violence in civil war. Previous research shows that the nature of violence-selective versus indiscriminate-is a function of control and the access to information that this provides (Kalyvas 2006:202-209). According to this theory, as the level of control exerted by a belligerent increases, the likelihood that that actor will employ indiscriminate violence diminishes. Control is inextricably linked to the levels of support for that actor and the amount of information it has. As active and passive support for an actor increase, so do the chances for collaboration, such as through furnishing intelligence. Greater access to local knowledge through local militias enhances the state's ability to selectively target their opponents and increase their control over local populations. Indeed, Peic (2014) shows that states that support civilian defense forces are more likely to defeat an insurgency, due to the local information they can provide. Thus by helping to reduce the problem of insurgent identification and enhancing levels of state control, we expect the presence of civilian defense forces to significantly decrease indiscriminate government-sided violence. From this discussion we derive our first hypothesis. 
Hypothesis 1: The presence of a civilian defense force reduces indiscriminate state violence against civilians.

\section{The Wider Effects of Civilianizing Warfare}

The advantages an incumbent gains from civilian defense forces produce the opposite effect for insurgents. Civilian defense forces inherently oppose the rebels. They reduce insurgent ability to evade detection and maintain control of local populations. Civilian defense forces drive a wedge between the rebels and civilians. The defection of civilians from the insurgents to the incumbents diminishes insurgent control and increases the likelihood of indiscriminate insurgent violence (Kalyvas 1999:269, 276; 2006:224-226). Faced with hostile civilians and a declining level of control, insurgents respond violently, employing more indiscriminate forms of violence where they have weaker levels of control (Downes 2007:424, 2008:251-254; Eck and Hultman 2007:241; Raleigh 2012:469-470; Weinstein 2007:203-204; Wood 2010). In other words, we expect a civilian defense force will produce an increase in insurgent attacks towards the civilian populations that no longer support them. This leads to our second hypothesis.

Hypothesis 2: The presence of a civilian defense force increases indiscriminate rebel violence against civilians.

Civilian defense forces can also polarize local communities. This produces higher levels of violence as incumbents and insurgents seek to gain the active, rather than passive, support of the community. Civilians become participants in the civil conflict. They actively support and collaborate with either the insurgents or the incumbents. Research indicates that in 
this environment people use these outlets to settle personal feuds, increasing inter-civilian violence and the overall number of fatalities (e.g. Kalyvas 2006:376).

In addition, a civilian defense force can reduce the cohesion of insurgent movements. The probability of insurgent defection increases when an incumbent is better equipped to identify insurgents and when a population is hostile to insurgent demands (Kalyvas 1999:275277). As Staniland (2014:40-49) argues, counterinsurgents diminish insurgent cohesion by starving insurgents of local support and incentivizing side-switching to the incumbent cause. The possibility of side-switching poses a serious threat to the strength and stability of the insurgency, and requires the group to focus violent attention on actual and potential defectors within their organizations and supporting populations (Bakke, Cunningham, and Seymour 2012:266-268; Lyall 2010:16-17; Staniland 2012). Ethnic cleavages and other social networks pervading insurgent groups can exacerbate this process (Lyall 2010; Staniland 2014:97). In this way the emergence of civilian defense forces can turn the insurgency in on itself. This increases the use of violence within insurgent groups as well as towards its civilian support base (as in hypothesis 2).

In this respect, we argue that the initiation of a civilian defense force intensifies violence within civil conflict. The cumulative effect of the increased ability of incumbents to target insurgents, increased insurgent targeting of civilians, insurgent infighting, and the general process of civilianizing civil conflict, is likely to produce an increase in the violence overall. From this discussion we derive our final hypothesis.

Hypothesis 3: The presence of a civilian defense force increases the overall fatalities during civil war.

\section{Research Design}


To test our hypotheses we apply a nested mixed-method research design (Lieberman 2005). We first assess our arguments using statistical analysis. After the primary analysis we then follow Lieberman's (2005:440-442) model testing small-N approach and assess the case of the self-defense militia in Iraq (2005-2009).

\section{Dependent Variables}

To evaluate hypotheses 1 and 2 we examine data on one-sided violence in civil conflict (Eck and Hultman 2007). This data provide a count of intentional and direct killings of civilians by both government and rebel agents between 1989 and $2005 .{ }^{1}$ The data only capture a sub-set of civilian conflict deaths. They exclude a range of factors such as unintentional killings, indirect deaths, and extrajudicial executions. Thus whilst our previous discussion spoke broadly about violence, our statistical analysis focuses only on the most deadly subset of violence in which governments and non-state groups deliberately and directly target civilians.

\footnotetext{
${ }^{1}$ Using data at the yearly level of aggregation has limitations. Often incidents of one-sided violence are not centrally planned and should theoretically be analyzed as individual forms of political violence (Schneider and Bussmann 2013). However, disaggregating to the event level is limits comparability and presents additional data challenges, not least the lack of geo-coded militia data (Raleigh 2012). Similarly, aggregating the conflict fatalities or including an averaged count of fatalities across a conflict discards important detail that is held at the conflict year. In particular, cases that feature civilian defense forces tend to exhibit important within-case variations that would be lost in an aggregate conflict episode analysis. We therefore prefer the yearly counts of one-sided violence to alternatives such as event or aggregated conflict analysis.
} 
Hypothesis 1 makes claims relating to government violence against civilians. Our dependent variable in our first analysis is thus the count of civilian deaths produced by the state in each conflict year. ${ }^{2}$ This produces 529 country-year observations. Hypothesis 2 focuses on insurgent violence against civilians. Our dependent variable in this analysis is a dyadic indicator recording the count of civilians killed by each rebel group in a civil conflict year (Harbom, Melander, and Wallensteen 2008). ${ }^{3}$ This results in 820 dyad-year observations, including 203 rebel groups in 114 conflicts, across 70 states. Finally, hypothesis 3 focuses upon the total fatalities in civil conflict. The dependent variable in this analysis is the best estimates of the number of battle-related deaths in each conflict year (Lacina and Gleditsch 2005), which results in a population of 615 conflict years. ${ }^{4}$

\section{Independent Variable}

\footnotetext{
${ }^{2}$ In our analysis of government violence we assess the number of fatalities attributed to the state in a conflict year. As a robustness check, we sum the number of state fatalities with the deaths attributed to six non-state groups that are included with the UCDP data as independent actors but also classified as pro-government militias, and the results remain consistent. We also exclude Rwanda in 1994 as this is an extreme outlier. However, when we include the Rwandan case, or include a dummy variable for this case, the effect of civilian defense forces remains the same.

${ }^{3}$ In our analysis of rebel violence we assess only those cases in which a rebel movement is in contest with a state actor, and exclude all other dyads involving non-state groups.

${ }^{4}$ A full list of descriptive statistics is available in supplementary appendix I
} 
We use the pro-government militia database to operationalize civilian defense forces (Carey, Mitchell, and Lowe, 2013). This cross-national database captures the presence of progovernment militias by applying a uniform coding scheme to publically available news sources. It defines pro-government militia as "a group that is identified by sources as progovernment or sponsored by the government (national or sub-national), that is not part of the regular security forces, is armed, and has some level of organization” (Carey, Mitchell, and Lowe, 2013:252). The dataset identifies 331 pro-government militias active between 1981 and 2007. In addition to the raw data, the pro-government militia dataset includes an online relational database. This provides the primary news sources used to code the original data. Using this material we code civilian defense forces as militia groups that meet the following coding criteria ${ }^{5}$ :

(1) Participants: the group is composed mainly of civilians.

(2) Area of operation: forces remain within the neighborhood, village, or region/department from which they were recruited. Members remain in their own homes rather than reporting to a centralized operational base.

(3) Defensive role: civilians mobilize for neighborhood/village security and limited defensive capabilities against insurgents. This can include intelligence gathering and denunciations of insurgents and insurgent sympathizers present or living in the area of operation. It can also include direct combat with insurgents in expelling members of the insurgency from the civilian defense force community or denying insurgents access.

\footnotetext{
${ }^{5}$ For more information on coding procedure see supplementary appendix II
} 
We relied primarily on the news sources within the Pro-Government Militia online relational database in order to code civilian defense forces (Carey, Mitchell, and Lowe 2013). On the rare occasions when we had insufficient information within the existing online database sources, we undertook additional research into the characteristics of the group using major news sources such as BBC World Service and The Guardian. ${ }^{6}$ We systematically reviewed all 331 entries for the 3 essential civilian defense force criteria. We only classified groups that met all three criteria as civilian defense forces. Given the relative clarity of coding criteria for civilian defense forces, identifying the requisite characteristics was straightforward in most cases. ${ }^{7}$ For example, media descriptions of the Rondas Campesinas in Peru describe their intended purpose as "to enable the campesinos [farmers] to defend themselves against Sendero” (The Guardian 1984 as cited in Mitchell, Carey and Lowe Online Database 2013). We used descriptors such as "local” "villagers" "self-defense" "defending their own communities” "grassroots”, amongst many others as key initial indicators of groups likely to fulfill all the criteria.

In total, 50 of the 331 pro-government militias met all three criteria and we coded each of these as civilian defense forces. ${ }^{8}$ We capture the presence of a civilian defense force using a

\footnotetext{
${ }^{6}$ We undertook research using Lexis Nexis.

${ }^{7}$ Checks for inter-coder reliability showed at least 95\% consistency between coders.

${ }^{8}$ For a full list of civilian defense forces see supplementary appendix III. For descriptive analysis of key civilian defense force characteristics see supplementary appendix IV.
} 
dummy variable, with all country years in which a civilian defense force was present coded as 1 , and 0 in all other cases. ${ }^{9}$

\section{Controls}

We include a number of controls to account for potentially confounding variables and competing arguments. Firstly, we include indicators of key state characteristics that influence the dynamics of civil violence. We expect that democracies are more prone to suffer rebel violence against civilians, whilst autocracies more likely to involve high intensity violence and government targeting of the civilian population. To account for this we include a measure of regime type taken from the Polity IV dataset (Marshall and Jaggers 2006). The dynamics of violence within a state are also closely related to economic development. States with a stronger economic base are better equipped to protect their population from rebel assaults and less likely to require violence to gain civilian collaboration. To account for this we include a lagged indicator of GDP per capita (Gleditsch 2002). States that contain large populations and inaccessible terrain are more challenging to control, which could increase the likelihood of one-sided violence. We control for this relationship by including the natural log of the state's population (Gleditsch 2002) and the logged percentage of mountainous terrain (Fearon and Laitin 2003). Finally, we include an indicator of the size of a state's excluded population

\footnotetext{
${ }^{9}$ We follow the pro-government militia database and consider all militia forces that share a similar organization and political basis as part of the same group. This approach means that in more than $75 \%$ of cases there is only ever one civilian defense force operating within a state. As a robustness check we replaced our dichotomous independent variable for a count variable indicating the number if independent groups within a state, there is no significant difference in our results.
} 
(Cederman, Wimmer, and Min 2010). We expect higher levels of exclusion to increase all forms of violence. ${ }^{10}$

We also include controls to account for key conflict characteristics. Firstly, to ensure that our results are driven by civilian defense forces, and not pro-government militias more generally, we account for the presence of militias that are "informally" or "semi-officially" linked to the state (Mitchell, Carey and Butler 2013). As we discuss above, other militias (e.g. non-civilian defense groups) can take a variety of forms. Yet in the absence of clear conceptual categories for other sub-sets of militia, controlling for other groups in relation to their link with the state offers the most theoretically meaningful method. ${ }^{11}$ We include an indicator of incompatibility, based on the belief that conflicts fought for control of the state are more often of a high intensity and involve civilian targeting. We include an indicator of conflict duration that records the number of years since the start of the conflict episode. Over time we expect a reduction in all forms of violence. To capture the distribution of capabilities within a conflict we include a ratio of the number of all rebel forces operating within the state's territory to the

\footnotetext{
${ }^{10}$ We do not include country-fixed effects on account of the low level of within-case variation on our independent variable (e.g. 85\% of conflicts in the dyadic dataset always or never feature a civilian force). For cases in which an explanatory variable is partially time invariant, the inclusion of unit dummies eliminates 'too much’ cross-sectional variance and would severely bias our estimates (Plümper, Troeger and Manow 2005:330334; Huber and Stephens 2001).

${ }^{11}$ We also run the analysis using a dichotomous variable to account for the presence of all other militia groups. Our main findings remain consistent regardless of the approach adopted. We include the disaggregated measures of other militias as they offer additional theoretical insights.
} 
total number of government troops (Wood, Kathman and Gent 2012). ${ }^{12}$ We expect relatively stronger rebellions to increase the overall conflict severity, but have only a minor effect on the violence against civilians (Wood 2012). We include the natural log of the total number of battlefield deaths in each conflict year (for the analysis of civilian deaths) (Lacina and Gleditsch, 2005) as conflicts of a greater intensity might be more likely to involve violence against civilians. Further, we include the log-transformed count of civilian killings the opposing actor committed in each of the civilian violence models. We expect increased government or rebel violence to lead to an increase in their opponent's use of repressive force (Wood, Kathman and Gent 2012). We also include our own measure to account for the presence of a peacekeeping operation that can reduce the use of all one-sided violence (Hultman, Kathman and Shannon 2013). Finally, we include a dummy variable indicating whether the conflict actor perpetrated one-sided violence in the previous year to account for potential problems of temporal dependence. ${ }^{13}$

\section{Statistical Analysis}

We present the statistical results in Tables II, III and IV. As all three dependent variables are counts of fatalities, we estimate negative binomial regression models. Table II includes the analysis that assesses hypothesis 1 (government violence), Table III, hypothesis

\footnotetext{
${ }^{12}$ For the analysis of rebel violence the ratio measures the individual rebel organization in relation to the number of government troops (Wood, Kathman and Gent 2012).

${ }^{13}$ See robustness checks for a number of alternative specifications.
} 
2 (rebel violence), and Table IV, hypothesis 3 (conflict intensity). All results support our hypothesis.

Hypothesis 1 posited that the presence of civilian defense forces helps governments reduce the problems associated with insurgent identification. We argued that local civilian militia would increase the ability of the state to selectively target insurgents, lowering the use of indiscriminate violence against their civilians. The analysis provides strong support for this claim.

Model 1 assesses the effect of a civilian defense force on one-sided government violence whilst controlling for potentially confounding state characteristics. As expected, the civilian defense force variable is negative and statistically significant. This effect remains consistent when we add controls that account for the conflict context (Model 2).

Table II: Binomial Regression Models -Government Violence against Civilians

(1)

Government Violence (State Controls)
(2)

Government Violence (Full Model) 
Civilian Defense Force

Polity IV

GDP per capita (t-1)

Population (l) (t-1)

Mountainous terrain (l)

Size of Excluded Population

Informal Militia

Semi-official Militia

Government Incompatibility

Conflict Duration

Insurgent Relative Capacity

Conflict Intensity (l)

Rebel Violence

Peacekeeping Operation

Government Violence $\quad 2.225^{* * *}$

Dummy (t-1)

Constant

Alpha

$\begin{array}{cc}-0.098^{* *} & -0.071 \\ (0.035) & (0.063) \\ 0.063 & -0.055 \\ (0.246) & (0.416) \\ 0.166 \dagger & 0.094 \\ (0.094) & (0.144) \\ 0.160 & 0.289 \\ (0.183) & (0.255) \\ 1.312^{*} & 2.335^{* *} \\ (0.660) & (0.818)\end{array}$

$0.575^{*}$

(0.250)

$-0.457$

(0.438)

$-1.066^{*}$

(0.484)

$-0.066^{* * *}$

(0.012)

$-0.239$

(0.186)

0.160

(0.134)

0.031

(0.095)

$-0.485$

(0.431)

82)

$\left(0.32 .433^{* * *}\right.$

51)

0.112

(2.798)

1.898

(4.595)

$2.460^{* * *}$

508 $-1409.5903$

523

$-1443.185$

$2.581^{* * *}$

Log-Likelihood

(0.4 Variable

Robust Standard errors (clustered on conflict) in parentheses $\dagger p<0.10^{*} p<0.05,{ }^{* *} p<0.01,{ }^{* * *} p<0.001$. $(\mathrm{t}-1)=$ Lagged Variable. $(\mathrm{l})=$ Logged Variable Table III: Binomial Regression Models -Insurgent Violence against Civilians

(3)

Rebel Violence (State Controls)

\section{(4)}

Rebel Violence

(Full Model)

\section{Civilian Defense Force}




\begin{tabular}{|c|c|c|c|}
\hline Polity IV & $\begin{array}{l}0.101^{*} \\
(0.043)\end{array}$ & & $\begin{array}{l}0.141^{* *} \\
(0.044)\end{array}$ \\
\hline GDP per capita (t-1) & $\begin{array}{c}-1.063^{* * *} \\
(0.237)\end{array}$ & & $\begin{array}{c}-0.956^{* * *} \\
(0.246)\end{array}$ \\
\hline Population (l) (t-1) & $\begin{array}{l}-0.047 \\
(0.130)\end{array}$ & & $\begin{array}{l}0.090 \\
(0.137)\end{array}$ \\
\hline Mountainous Terrain (l) & $\begin{array}{l}-0.354^{* *} \\
(0.136)\end{array}$ & & $\begin{array}{l}-0.298^{*} \\
(0.125)\end{array}$ \\
\hline $\begin{array}{l}\text { Size of Excluded } \\
\text { Population }\end{array}$ & $\begin{array}{l}2.856^{* *} \\
(1.054)\end{array}$ & & $\begin{array}{c}0.828 \\
(0.788)\end{array}$ \\
\hline Informal Militia & & & $\begin{array}{l}-0.973^{*} \\
(0.426)\end{array}$ \\
\hline Semi-official Militia & & & $\begin{array}{c}0.383 \\
(0.420)\end{array}$ \\
\hline $\begin{array}{l}\text { Government } \\
\text { Incompatibility }\end{array}$ & & & $\begin{array}{c}0.569 \\
(0.471)\end{array}$ \\
\hline Conflict Duration & & & $\begin{array}{l}-0.039^{*} \\
(0.017)\end{array}$ \\
\hline $\begin{array}{l}\text { Insurgent Relative } \\
\text { Capacity }\end{array}$ & & & $\begin{array}{l}-0.087 \\
(0.131)\end{array}$ \\
\hline Conflict Intensity (l) & & & $\begin{array}{l}0.504^{* * *} \\
(0.077)\end{array}$ \\
\hline Government Violence & & & $\begin{array}{c}0.087 \\
(0.075)\end{array}$ \\
\hline Peacekeeping Operation & & & $\begin{array}{l}0.672 \dagger \\
(0.374)\end{array}$ \\
\hline $\begin{array}{l}\text { Rebel Violence Dummy } \\
\text { (t-1) }\end{array}$ & $2.302^{* * *}$ & (0. $\quad 1.981^{* * *}$ & 212) \\
\hline Constant & $\begin{array}{l}11.25^{* * *} \\
(2.623)\end{array}$ & & $\begin{array}{l}5.750^{*} \\
(2.739)\end{array}$ \\
\hline Alpha & $\begin{array}{l}2.821^{* * *} \\
(0.150)\end{array}$ & & $\begin{array}{l}2.524^{* * *} \\
(0.147)\end{array}$ \\
\hline No. of Observations & 820 & & 714 \\
\hline Log-Likelihood & -2011.1747 & & -1898.0088 \\
\hline
\end{tabular}


To examine the substantive effect of the relationship between civilian defense forces and state targeting of civilians we estimate predicted values. ${ }^{14}$ The results show that the presence of a civilian defense force reduces the predicted number of state killings of civilians from 66 to 22, a reduction of 67\%. This finding strongly supports the argument underpinning hypothesis 1: when states recruit civilian defense forces, their ability to effectively target insurgents reduces the intensity of state violence against civilians.

The control variables perform broadly in line with prior research. Militias informally linked to the state significantly increase government violence. This suggests that the capacity to overcome problems of identification is unique to civilian defense groups. It also extends previous research that links informal groups and state human rights abuses. Autocratic institutions, a larger 'excluded' population, and a history of civilian targeting each significantly increase the likelihood of government violence, whereas increased conflict duration and government incompatibilities reduce the likelihood of one-sided government violence.

Moving to the second phase of analysis, hypothesis 2 predicted that the formation of civilian defense forces would increase rebel violence against civilians. We argued that insurgents are more likely to target civilians when they actively signal their collaboration with the state by forming a civilian defense force. The results depicted in Table III offer firm support for our claims. As with the prior analysis, we first assess the influence of civilian

\footnotetext{
${ }^{14}$ Predicted values generated using the CLARIFY package in STATA 12 (King, Tomz and Wittenberg, 2000). All control variables were held at their mean or modal values assuming that the actor perpetrated some form of one-sided violence in the previous year.
} 
defense forces whilst controlling for state characteristics (Model 3). We then include additional controls to account for the conflict context (Model 4).

In all models the civilian defense force variable produces a positive and statistically significant effect on the use of rebel violence against civilians. As we predicted in hypothesis 2, the presence of a civilian defense force appears to refocus the targets of insurgent violence and increases insurgent's incentives to target civilians. Substantively, the presence of a civilian defense force increases the predicted number of insurgent killings from 63 to 153, an increase of $143 \%$. This effect is consistent across all specifications including both state and conflict controls.

Additional findings also support our theoretical claims. The intensity of one-sided rebel violence is lower within autocratic and economically strong states, and those that contain less inaccessible terrain. This suggests that states which are unfavorable to insurgency have lower levels of insurgent control and thus increase the likelihood of rebels targeting civilians indiscriminately.

Other control variables also perform in accordance with our expectations. High intensity civil conflicts, in particular those with a history of one-sided violence, are more likely to suffer intense levels of rebel violence. A more significant "excluded” population increases the level of rebel violence, and conflict duration has a negative effect on insurgent violence. Informal militias again have the opposite effect to civilian defense groups. Informal militias significantly reduce insurgent violence against civilians. This finding points to the inefficiency of state-sponsored attacks against civilians, for the violent actions of informal groups appear to reduce rebel reliance on violent methods to foster domestic support. 


\begin{tabular}{|c|c|c|}
\hline & (5) & (6) \\
\hline & $\begin{array}{l}\text { Conflict Intensity } \\
\text { (State Controls) }\end{array}$ & $\begin{array}{l}\text { Conflict Intensity } \\
\text { (Full Model) }\end{array}$ \\
\hline Civilian Defense Force & $\begin{array}{l}0.928^{* *} \\
(0.287)\end{array}$ & $\begin{array}{l}1.231^{* * *} \\
(0.223)\end{array}$ \\
\hline Polity IV & $\begin{array}{l}-0.009 \\
(0.027)\end{array}$ & $\begin{array}{c}-0.011 \\
(0.025)\end{array}$ \\
\hline GDP per capita (t-1) & $\begin{array}{l}-0.135 \\
(0.235)\end{array}$ & $\begin{array}{c}0.020 \\
(0.164)\end{array}$ \\
\hline Population (l) (t-1) & $\begin{array}{l}-0.162 \\
(0.111)\end{array}$ & $\begin{array}{c}0.120 \\
(0.095)\end{array}$ \\
\hline Mountainous terrain (l) & $\begin{array}{c}0.133 \\
(0.129)\end{array}$ & $\begin{array}{c}0.096 \\
(0.084)\end{array}$ \\
\hline Size of Excluded Population & $\begin{array}{l}1.397^{*} \\
(0.580)\end{array}$ & $\begin{array}{l}1.139^{*} \\
(0.474)\end{array}$ \\
\hline Informal Militia & & $\begin{array}{l}0.690^{* * * *} \\
(0.197)\end{array}$ \\
\hline Semi-official Militia & & $\begin{array}{l}-0.178 \\
(0.222)\end{array}$ \\
\hline Government Incompatibility & & $\begin{array}{l}-0.221 \\
(0.234)\end{array}$ \\
\hline Conflict Duration & & $\begin{array}{l}-0.042^{* * * *} \\
(0.011)\end{array}$ \\
\hline Insurgent Relative Capacity & & $\begin{array}{l}0.354^{* * * *} \\
(0.079)\end{array}$ \\
\hline Peacekeeping Operation & & $\begin{array}{c}0.057 \\
(0.329)\end{array}$ \\
\hline Constant & $\begin{array}{l}8.204^{* * *} \\
(2.201)\end{array}$ & $\begin{array}{l}5.718^{* * * *} \\
(1.709)\end{array}$ \\
\hline Alpha & $\begin{array}{l}0.555^{* * * *} \\
(0.072)\end{array}$ & $\begin{array}{l}0.293^{* * * *} \\
(0.070)\end{array}$ \\
\hline No. of Observations & 617 & 583 \\
\hline Log-Likelihood & -4534.208 & -4220.492 \\
\hline
\end{tabular}

The final hypothesis predicted that the presence of a civilian defense force would increase the overall fatalities in civil conflict. The combined effect of increased numbers of state-sided participants, more effective targeting of the insurgency, and "softer" rebel civilian 
targets, we argued, increase the overall intensity of war. We present the results in Table IV. As with the prior analysis, we first control for state characteristics (Model 5). We then include additional conflict controls in a fully specified model (Model 6). In both models a civilian defense force has a strong positive and highly significant effect on the number of battle-related fatalities. As expected, the delegation of security roles to a civilian defense force appears to significantly increase the severity of civil war violence. Substantively, the presence of a civilian defense force increases the predicted number of fatalities by $241 \%$, rising from 220 to 751 predicted deaths.

Our analysis largely supports previous research. The relative strength of a rebel force is shown to have a positive effect on the intensity of civil conflict. Conflicts are more likely to assume a conventional nature and violent character when rebel forces grow to match the size of the state. As with prior analysis, “excluded” groups increase the overall intensity of a conflict, while a longer duration decreases the severity of the violence. Informal groups increase the overall fatalities in a civil conflict. Presumably their broader range of targets, wider geographic focus, and more offensive remit inflame civil strife. ${ }^{15}$

The combined results highlight the utility in disaggregating between forms of violence in civil war. As our theoretical discussion predicted, civilian defense forces produce quite different effects on government, rebel, and overall civil violence. In line with previous literature, we find varied effects for a number of our controls. Informal militias, compared to civilian defense groups, have the opposite effect on one-sided violence. Informal militias

\footnotetext{
${ }^{15}$ Predicted values reveal the conflict-intensifying effect is greater for civilian defense groups than for other militia.
} 
significantly increase government violence, but reduce insurgent violence against civilians. Militias that are semi-officially linked to the state do not have a significant effect on any form of violence. These groups tend to most closely approximate conventional armed forces, and it is therefore perhaps not surprising that conflicts involving semi-official groups are not clearly distinguishable from those involving only conventional forces. Democratic states are more likely to suffer rebel violence against civilians, whilst non-democratic states are more likely to undertake government-led violence. The nature of the regime has little effect on the overall conflict severity. Economic development decreases the likelihood of all forms of violence against civilians, but only significantly reduces rebel-led violence. A greater excluded population increases all forms of violence significantly. Mountainous terrain significantly reduces the likelihood of rebels targeting civilians, but has no real effect on any other form of violence. More generally, we have shown that the relative strength of a rebel force has a positive effect on the intensity of civil conflict, but does not produce a significant effect on the likelihood of either government or insurgent violence against civilians. This supports previous research that shows that changing the balance of power within a conflict, rather than specific power configurations, is the key driver of civilian violence (Wood, Kathman and Gent 2012). Increased conflict intensity is more likely to produce government and rebel targeting of civilians, but the effect is only significant for rebel violence. It appears that one-sided violence is not a reciprocal process, as neither government nor rebel violence has a significant effect on the intensity of their opponent's attacks. Increased conflict duration reduces the likelihood of all forms of violence. Finally, as we would expect, a history of rebel or government violence strongly increases the likelihood of the same actor subsequently targeting civilians.

\section{Robustness Checks}


To ensure that our results are robust we change a variety of model specifications and rerun the estimates. ${ }^{16}$ Firstly, to ensure that we have not omitted any other key variables, we rerun our analysis including a number of additional controls that previous research suggests might influence the dynamics of civil violence. We add controls for: multiple rebel groups, democratic aid dependence, distance to the nearest democracy, the size of conflict area, ethnic fractionalization and the presence of natural resources. Our results remain robust in all model specifications.

Secondly, including a lagged dependent variable to account for temporal dependence can sometimes lead to inconsistent estimates (Achen 2000; Brandt and Sandler 2012). To evaluate the robustness of our findings we rerun the analysis using (i) dummy variables to account for one-sided violence in the previous 2, 3, and 5 years; (ii) a count of fatalities in the previous 1, 2, 3 and 5 years; (iii) the "year” variable to account for any linear time trend; (iv) year-fixed effects to account for a time trend and common shocks; (v) a count of the years since the last fatality (along with square and cubic terms); ${ }^{17}$ finally, (vi) we remove all temporal controls. Our results are robust regardless of the method used to account for temporal dependence.

Thirdly, using the conflict/dyad year as the unit of analysis also increases the likelihood of a small selection of conflicts biasing the results. We therefore rerun the analysis excluding the most deadly civil conflict years. Our key findings are robust even when we

\footnotetext{
${ }^{16}$ The data, replication materials, and output from all the robustness checks are available on the authors website.

${ }^{17}$ This is a modified version of the methodology suggested by Carter and Signorino (2010) for binary models.
} 
remove the most deadly years of civil conflict and civilian targeting from the analysis. ${ }^{18}$ However, taking yearly measurements of fatality counts over the course of a conflict also risks artificially reducing the standard errors by inflating the number of observations. To ensure that our findings are not biased in this manner, we assess the effect of civilian forces on onesided violence across conflict episodes. ${ }^{19}$ The results complement our prior analysis, suggesting that the presence of a civilian defense force during a civil war reduces the likelihood of the government targeting civilians, but increases the likelihood of one-sided rebel violence.

Finally, civilian defense forces could quite feasibly be the result rather than the cause of violent contexts. To account for potential endogeneity, we undertake matching to pair observations that featured a civilian defense force with similar observations without a civilian defense force. This process removes observations without civilian defense forces that have no

\footnotetext{
${ }^{18}$ For rebel violence we excluded DRC-AFDL (1996, 1997), Bosnia-Serbian Irregulars (1992 \& 1995), DRCRCD (1998). For government violence we excluded Sudan (2004), DRC (1997), Rwanda (1994, 1997), Afghanistan (1998). For conflict severity we excluded Congo-Cobras (1997), Angola-UNITA (1993), EthiopiaEPRDF (1989), Ethiopia-Military Faction (1990), and Ethiopia-EPRDF (1990).

${ }^{19}$ Cases in which civilian defense forces were present in some but not all of the conflict years are challenging to assess using the conflict episode. To overcome this, we use a number of different measures, including a ratio variable capturing the number of years in which the militias were present relative to the total conflict years; a dummy variable indicating if a civilian defense force was in all, $75 \%$ or $50 \%$ of the conflict years; and a dummy variable indicting the presence of a civilian defense force at any point during the conflict. The effect is largely consistent across the different measures.
} 
analogue amongst the cases in which a civilian defense force was active. ${ }^{20}$ By preprocessing our data in this manner we can assess the effect that civilian defense forces have independent of the conflict dynamics that might be more likely to produce such groups. We identify pairs using the MatchIt package in R, adopting 1:1 nearest neighbor matching with replacement (Ho et al. 2006). This produces 189 pairs of control and treatment observations from the original sample of 529 conflict years, and 266 pairs of control and treatment observations from the original sample of 820 conflict dyad years. ${ }^{21}$ Our analysis of the matched dataset adds further support for our hypothesis. Once again, civilian defense forces produce a strong and significant effect in the direction we predicted for all three forms of violence. This adds further support to our theoretical claims and helps to address confounding explanations related to endogeneity.

\section{Case Analysis: Iraq}

For a deeper assessment of our causal argument we undertake a 'model testing' case analysis (Lieberman 2005). We focus on civilian defense forces in Anbar province, Iraq (20052009). In Iraq, the civilian defense militias formed here first. Anbar is also one of the regions in which they were most active. It therefore represents an appropriate case to assess the internal validity of our argument.

\footnotetext{
${ }^{20}$ For more information on matching see Ho et al. 2007; Lyall 2010.
}

\footnotetext{
${ }^{21}$ Balance tests reveal that these pairs are closely matched, meeting or exceeding the standard for variance. For example, all variables receive a value of $\leq 0.25$ for standardized bias (e.g. the difference in the means of the treated and control groups, divided by the standard deviation of the treated group); this is considered a "good match” (Ho et al. 2007, 23fn15).
} 


\section{Sunni Militias and Coalition Violence}

In 2004 Coalition forces lost control in Anbar. Hampered by problems associated with insurgent identification, Coalition military action regularly resulted in civilian casualties (Macdonald 2014:201). For example, in 2005, Coalition forces committed approximately 500 civilian killings in Anbar province alone. The violent Coalition retaking of Fallujah and the Haditha incident perhaps best exemplifies this (What Happened in Haditha? 2008).

US military commanders changed this situation towards the end of 2006. They harnessed the shifting alliances of Sunni tribes that had independently begun to defect from the insurgency (McCary 2009). This “Sunni Awakening” saw local Sunnis assume responsibility for security in their community. US forces officially supported the Awakening in September 2006 with the establishment of the Anbar Awakening Council (Biddle, Friedman, and Shapiro 2012:19-20; McCary 2009; Montgomery and McWilliams 2009:13,46). In 2007, the US established the Sons of Iraq program to institutionalize these Sunni militias. ${ }^{22}$ With US support, the "Sons” expanded rapidly. By 2008, 100,000 militias expanded across more than two-thirds of Iraqi provinces, each “Son” receiving \$300 monthly as salary for their services (Bruno 2008; SIGIR 2011:15-19).

Information from the "awakened” militias allowed Coalition forces to effectively focus their military firepower on insurgents. This helped to reduce civilian fatalities and increase the effectiveness of the 2007 US troop surge (Biddle, Friedman, and Shapiro 2012:25-33; Clayton and Thomson 2014:929; Macdonald 2014:212-214). We depict the effects of militias in Figure

\footnotetext{
${ }^{22}$ Originally titled the "Concerned Local Citizens" - reflecting its local defense orientation.
} 
I using the number of incidents a month in which the Coalition forces killed at least one civilian in Anbar province. The early phases of the counterinsurgency elucidate the problems associated with insurgent identification. From January 2005 until the formation of the Awakening Council in September 2006,Colaition forces perpetrated an average 12 incidents and 32 civilian deaths each month. While there were cases of side-switching during this time, the US military did not capitalize on information gains through these groups until the formation of the Awakening Council. By the second half of 2007, incidents were down by $50 \%$ and Coalition forces reduced their number of civilian killings to an average of 4 a month.

***** INSERT FIGURE ONE ABOUT HERE

Whilst violence against civilians declined, the Coalition's ability to target insurgents increased. The Iraq war logs released on Wikileaks reveal that insurgent kills rose to an average of 200 a month in the period following the Awakening. ${ }^{23}$ According to official military figures, the combination of the Awakening and the subsequent surge led to a $25 \%$ rise in insurgents killed from 2006 to 2007 (Cordesman and Davies 2008; 525-526). Moreover, anecdotal evidence contained in military reports details how Sunni tribal militias gathered intelligence to aid the US military in more selectively targeting insurgents (Ahmed 2008:7; Koloski and Kolasheki 2009:41-53; Smith and Macfarland 2008:44-45). According to a US military report, "Local citizens knew most of the members of their communities and could easily pick out those

\footnotetext{
${ }^{23}$ The only period in which insurgent kills were higher in Anbar province was the battle for Fallujah in November/December 2004. See, the Iraq War Logs 2010.
} 
who did not belong. They knew which neighbors were tacit or active supporters of insurgent groups. They knew who could provide timely and accurate information on insurgent activity, and they gave the squadron commander vital human intelligence essential to success” (Koloski and Kolasheki 2009:41-53). The Sons denounced enemies and rid the areas of foreign fighters but also provided “a great deal of intelligence on members of insurgent groups, many of whom were members of their tribes” (Ahmed 2008:7). For example, the number of insurgent weapons caches Coalition forces found in Anbar province went from 692 in 2004 to 1,222 in 2006 and then up to 2,111 between January and September of 2007 (Cordesman and Davies 2008:522).

\section{Civilianizing the Iraq War}

Civilian defense groups also affected the targets of insurgent violence. According to military accounts, insurgents responded to civilian defense forces by targeting tribal leaders and civilians who had made the switch, as well as those who were contemplating it. Insurgents attempted to punish them for their abdication and deter future defections (Finer and Nickmeyer 2005; Long 2008:79-81; Smith and Macfarland 2008:49).

Evidence of the number of insurgent attacks that produced at least one civilian death supports our claims. As Figure II shows, a trend in the increase of insurgent attacks began during 2005 as Sunni tribes started to defect from the insurgency (Biddle, Friedman, and Shapiro 2012:19-20; McCary 2009:48-49). Insurgent attacks peaked in the month in which local tribal groups formed the Awakening council. Insurgent attacks continued in high numbers for the following year as numerous tribes realigned against their former allies. During the year that followed the Sunni Awakening, insurgents killed 637 civilians in 195 separate incidents. This was the most deadly year for civilians in Anbar province. 
US Major Smith and Colonel Macfarland describe how members of the insurgency "attempted to intimidate future recruits by murdering and desecrating the body of a local sheik who had been instrumental in our early push at recruiting tribe members into the ISF [Iraqi Security Forces]” (Smith and Macfarland 2008:49). The remaining insurgent blocks targeted tribes who had made the switch, as well as those who were contemplating it, to condemn their abdication and deter future defections (Finer and Nickmeyer 2005; Macfarland 2008:48-50; Long 2008:79-81). Indeed, insurgents assassinated Sheik Sattar Al-Rishawi, one of the progenitors of the Sunni awakening and the Sons of Iraq program, in 2007. Many Sons of Iraq members and those civilians who played a role in the Sunni awakening became victims of insurgent retribution.

\section{*****INSERT FIGURE II ABOUT HERE*****}

\section{Conflict Intensification}

The emergence of Sunni militias also increased violence overall. Evidence from the Iraq war logs illustrates the severity of the violence in this period. The total fatalities (e.g. coalition, civilian, and insurgent) grew quickly with the formation of Sunni militia, increasing the average fatalities from 162 a month at the start of 2005, to an average of 289 in the six months following the Awakening. As we already discussed, the enhanced Coalition targeting of insurgents coupled with increased rebel violence towards civilians intensified the conflict. In addition, interviews of Sunni civilians, militias and former insurgents point to the important role that insurgent fragmentation played in this process (Montgomery and McWilliams 2009:66, 91). The Awakening split the insurgency and those supporting it. It pitted "flipped” tribal militias against foreign al-Qaeda elements as well as members of their own tribes who 
still sympathized with or were active in the insurgency. For example, one Iraqi interviewee (as cited in Montgomery and McWilliams 2009:102) related that "Some people from al-Qaeda changed their faces. They are in the Awakening now. They didn't join us because they believe we are good, but to protect themselves. They saw who's winning, so they were with the Awakening. But when al-Qaeda was in, they were with al-Qaeda.” Colonel Macfarland (as cited in Montgomery and McWilliams 2009:178) described this process: "One by one, the local tribes are beginning to flip from either hostile to neutral or neutral to friendly.”

As this process unfolded, infighting ensued. For example, one Sheikh recalled how at one point not all members of his tribe had defected from the insurgency. He described infighting within his own tribe as well as with al-Qaeda (Montgomery and McWilliams 2009:81). He further described how both sides sought to punish defection in this period (Montgomery and McWilliams 2009:91-94). The formation of the Awakening Council was a "tipping point" in this regard. As Smith and Macfarland (2008:49) recount "Soon after the council ended, tribes began an independent campaign of eradication and retaliation against [alQaeda] members living among them.”

In summary, the “awakened” militias and Sons of Iraq effectively located insurgents. This helped the US military to target insurgents as well as reduce civilian fatalities. However, the militias provoked a response from insurgents. Insurgents retaliated against local communities in an attempt to punish defection and regain control. The Sunni realignment also caused defections and fragmentation within the insurgency, and drove a wedge between the local populations and the insurgents, intensifying the civil conflict but eventually choking the latter out of the area. 


\section{Conclusions}

In this article we argue that civilian defense forces constitute a unique type of progovernment militia and that such groups have specific effects on patterns of violence in civil war. Our evidence shows that civilian defense forces decrease incumbents' use of indiscriminate violence, but increase insurgent violence. We also demonstrate that by making civilians the center of the irregular war effort, civilian defense forces increase-at least in the short run — the overall fatalities in civil conflicts. This underscores the significance of civilian support and control in determining the type and level of violence in civil wars (Kalyvas 2006:111-145). Specifically, in accordance with existing research on one-sided violence against civilians, we find further evidence that actors tend to resort to indiscriminate violence where they enjoy only weak levels of control (Downes 2007:424; Eck and Hultman 2007:241; Valentino, Huth, and Balch-Linsay 2004:386-387; Weinstein 2007: 203-204; Wood 2010; Zahar 2000:110).

We contribute to the emerging body of literature centered on the effects of progovernment militias (Ahram 2011; Carey, Mitchell and Lowe 2013; Carey, Colaresi and Mitchell 2011, 2015; Peic 2014; Stanton 2015). We offer one of the first systematic investigations into the effects that militias exert on the dynamics of civil conflict. In doing so, we also develop further insight into different types of pro-government militias and why and how states make use of these differences. More generally, our arguments matter for understanding insurgent group fragmentation (Bakke, Cunningham and Seymour 2012; Driscoll 2012; Staniland 2014). While previous research stresses ethnic divisions (Lyall 2010; Staniland 2012), we highlight the importance of civilian support—both passive and activeto insurgents in explaining insurgent in-fighting. 
Finally, from a policy-making standpoint this article supports the established view that civilians in counterinsurgent roles can provide an effective strategy to separate insurgents from the local population (Galula 1964: 55-57; Jones 2012:15-16; McClintock 1992:251-252; Peic 2014:163). However, it opens significant normative questions given the effects that this strategy likely has on the dynamics and intensity of violence. From a more critical perspective, civilian defense forces are tantamount to a divide-and-rule- tactic. The delegation of security and coercion of civilians polarizes local relationships by forcing insurgents to respond to those that are now actively against them. Indeed, developing states often use civilian cleavages in this way to mute resistance to processes of state formation (Ahram 2011; Bakke 2015; Holden 2004; Thomson 1994; Tilly 2003). Similarly, conquering powers often use local collaborators in this manner within broader social networks of domination, often to the detriment of local populations (Macdonald 2014). Our findings therefore inform military debates on the effectiveness of civilian defense forces (Jones 2012), and provide evidence to show that incumbent forces that wish to use such tactics in the future should consider the serious ethical issues involved in placing civilians at the center of violence.

Our study intervenes in an interesting and understudied set of dynamics in the logic of violence in irregular wars. While our analysis reveals some significant insights into the effects of civilian mobilization into militia groups, we need further research to assess the effects of other types of militia groups. 


\section{References}

Achen, Christopher H. (2000) Why Lagged Dependent Variables Can Suppress the Explanatory Power of Other Independent Variables. Paper presented at the Annual Meeting of Political Methodology, Los Angeles, July 20-22.

Ahram, Ariel. (2011) Proxy Warriors. Stanford: Stanford University Press.

Ahram, Ariel. (2014) The Role of State-Sponsored Militias in Genocide. Terrorism and Political Violence 26(3): 488-503.

Ahmed, Farook. (2008) Sons of Iraq and Awakening Forces. Institute for the Study of War, Backgrounder 23, February 21. <http://www.understandingwar.org> (Accessed 15 March 2013)

Bakke, Kristin. (2015) Decentralization and Intrastate Struggles: Chechnya, Punjab and Québec. New York: Cambridge University Press.

Bakke, Kristin, Kathleen Cunningham, and Lee Seymour. (2012) A Plague of Initials: Fragmentation, Cohesion, and Infighting in Civil Wars. Perspectives on Politics 10(2): 265-283.

Barter, Shane Joshua. (2013) State Proxy Or Security Dilemma? Understanding Anti-Rebel Militias in Civil War. Asian Security 9(2): 75-92.

Belge, Ceren. (2011) State Building and the Limits of Legibility: Kinship Networks and Kurdish Resistance in Turkey. International Journal of Middle East Studies 43(01): 95114.

Biddle, Stephen, Jeffrey Friedman, and Jacob Shapiro. (2012) Testing the Surge: Why did Violence Decline in Iraq in 2007? International Security 37(1): 7-40. 
Brandt, Patrick and Todd Sandler. (2012) A Bayesian Poisson Vector Autoregression Model. Political Analysis 20(3): 292-315.

Bruno, Greg. (2008) The Role of the 'Sons of Iraq' in Improving Security. Washington Post 28 April. < http://www.washingtonpost.com/wpdyn/content/article/2008/04/28/AR2008042801120.html> (Accessed 2 September, 2015)

Campbell, Bruce B. (2002) Death Squads: Definition, Problems and Historical Context. In Death Squads in Global Perspective: Murder with Deniability, eds. Bruce B. Campbell and Arthur D. Brenner, vii-26. Basingstoke: Palgrave MacMillan.

Carey, Sabine C., Michael Colaresi and Neil J. Mitchell. (2015) Governments, Informal Links to Militias and Accountability. Journal of Conflict Resolution April (Online first): $1-21$.

Carey, Sabine, Michael Colaresi, and Neil J. Mitchell. (2011) Why Do Governments Use Militias? Working Paper. <http://www.sowi.uni-mannheim.de/militias/wpcontent/uploads/2011/05/CCM_WhyUseMilitias_Sept_27.pdf.> (Accessed 15 March, 2014)

Carey, Sabine, Neil Mitchell, and Will Lowe. (2013) States, the Security Sector and the Monopoly of Violence: A New Database on Pro-Government Militias. Journal of Peace Research 50(2) March: 249-58.

Carter, David, B., and Curtis S. Signorino. (2010) Back to the Future: Modeling Time Dependence in Binary Data. Political Analysis 18(3): 271-292.

Cederman, Lars-Erik, Andreas Wimmer and Brian Min. (2010) Why do ethnic groups rebel? New data and analysis. World Politics 62(1): 87-119. 
Clayton, Govinda and Andrew Thomson. (2014) The Enemy of My Enemy is My Friend... the Dynamics of Self Defense Forces in Irregular War: The Case of the Sons of Iraq. Studies in Conflict \& Terrorism 37(11): 920-935.

Cohen, Dara Kay and Ragnhild Nordas. (2015) Do States Delegate Shameful Violence to Militias? Patterns of Sexual Violence in Recent Armed Conflicts. Journal of Conflict Resolution April (Online first): 1-22.

Cordesman, Anthony and Emma Davies. (2008) Iraq’s Insurgency and the Road to Civil Conflict. Westport: Praeger.

Cunningham, Kathleen Gallagher. (2013) Actor Fragmentation and Civil War Bargaining: How Internal Divisions Generate Civil Conflict. American Journal of Political Science 57(3): 659-672.

Cunningham, Kathleen Gallagher. (2014) Inside the Politics of Self-Determination. New York: Oxford University Press.

Downes, Alexander B. (2008) Targeting Civilians in War. Ithaca: Cornell University Press.

Downes, Alexander B. (2007) Draining the Sea by Filling the Graves: Investigating the Effectiveness of Indiscriminate Violence as a Counterinsurgency Strategy. Civil Wars 9(4): 420-444.

Driscoll, Jesse. (2012) Commitment Problems or Bidding Wars? Rebel Fragmentation as Peace. Journal of Conflict Resolution 56(1): 118-149.

Eck, Kristine. (2015) Repression by Proxy: How Military Purges and Insurgency Impact the Delegation of Coercion. Journal of Conflict Resolution April (Online first): 1-23. 
Eck, Kristine and Lisa Hultman. (2007) One-Sided Violence Against Civilians in War: Insights from New Fatality Data. Journal of Peace Research 44(2): 233-246.

Fearon, James D., and David D. Laitin. (2003) Ethnicity, Insurgency, and Civil War. American Political Science Review 97(1): 75-90.

Finer, Jonathan and Ellen Knickmeyer. (2005) Sunni Leaders Attacked in Iraq. Washington Post, 19 August. < http://www.washingtonpost.com/wpdyn/content/article/2005/08/18/AR2005081800330.html> (Accessed 8 September 2015)

Fumerton, Mario and Simone Remijnse. (2004) Civil Defense Forces: Peru's CAC and Guatemala's PAC in Comparative Perspective. In Armed Actors: Organized Violence and State Failure in Latin America, eds. Kees Koonings and Dirk Kruijt, 52-72. London: Zed Books.

Galula, David. (1964) Counterinsurgency Warfare: Theory and Practice. New York: Praeger.

Gleditsch, Kristian Skrede. (2002) Expanded Trade and GDP Data. Journal of Conflict Resolution 46(5): 712-725.

Harbom, Lotta, Erik Melander, and Peter Wallensteen. (2008) Dyadic Dimensions of Armed Conflict, 1946-2007. Journal of Peace Research 45(5): 697-710.

Ho, Daniel., Kosuke Imai., Gary King, and Elizabeth Stuart. (2006) MatchIt: Nonparametric Preprocessing for Parametric Causal Inference. <http://gking.harvard.edu/matchit/>(Accessed 8 September 2015)

Ho, Daniel, Kosuke Imai, Gary King, and Elizabeth Stuart. (2007) Matching as Nonparametric Preprocessing for Reducing Model Dependence in Parametric Causal Inference. Political Analysis 15: 199-236. 
Holden, Robert. (2004) Armies without Nations: Public Violence and State Formation in Central America 1821-1960. Oxford: Oxford University Press.

Huber, E., and Stephens, J.D. (2001) Political choices in global markets: Development and crisis of advanced welfare states. Chicago, IL: Chicago University Press.

Hultman, Lisa, Jacob Kathman and Megan Shannon. (2013) United Nations Peacekeeping and Civilian Protection in Civil War. American Journal of Political Science 57(4): 875891.

Iraq War Logs. (2010) <http://www.theguardian.com/news/datablog/2010/oct/23/wikileaksiraq-data-journalism\#data> (Accessed February 2, 2015).

Jentzsch, Corinna, Stathis Kalyvas and Livia Isabella Schubiger. (2015) Militias in Civil Wars. Journal of Conflict Resolution April (Online first): 1-15.

Jones, Seth G. (2012) The Strategic Logic of Militia. Santa Monica: RAND Working Paper.

Kalyvas, Stathis. (2006) The Logic of Violence in Civil War. Cambridge: Cambridge University Press.

Kalyvas, Stathis. (1999) Wanton and Senseless? The Logic of Massacres in Algeria. Rationality and Security 11(3): 243-285.

King, Gary, Michael Tomz, and Jason Wittenberg. (2000) Making the Most of Statistical Analysis: Improving Interpretation and Presentation. American Journal of Political Science 44(2): 347-361.

Kilcullen, David. (2010) Counterinsurgency. Oxford: Oxford University Press. 
Klare, Michael T. (2004) The Deadly Connection: Paramilitary Bands, Small Arms

Diffusion, and State Failure. In When States Fail: Causes and Consequences, ed. Robert I. Rotberg, 116-135. Princeton: Princeton University Press.

Koloski, Andrew and John Kolasheki. (2009) Thickening the Lines: Sons of Iraq, A Combat Multiplier. Military Review 89 (1) (January): 41-53.

Lacina, Bethany and Nills Petter Gleditsch. (2005) Monitoring Trends in Global Combat: A New Dataset of Battle Deaths. European Journal of Population 21(3): 145-166.

Lieberman, Evan S. (2005) Nested Analysis as a Mixed-Method Strategy for Comparative Research. American Political Science Review 99(3): 435-452.

Long, Anthony. (2008) The Anbar Awakening. Survival: Global Politics and Strategy 50(2): $67-94$.

Lyall, Jason. (2010) Are Co ethnics More Effective Counterinsurgents? Evidence from the Second Chechen War. American Political Science Review 104(1): 1-20.

Macdonald, Paul. (2014) Networks of Domination: The Social Foundations of Peripheral Conquest in International Politics. Oxford: Oxford University Press.

Marshall, Monty G. and Keith Jaggers. (2006) Polity IV Project: Political Regime Characteristics and Transitions, 1800-2006.

<http://www.systemicpeace.org/polity/polity4.htm> (Accessed 13 March, 2013)

Mazzei, Julie. (2009) Death Squads Or Self-Defense Forces? How Paramilitary Groups Emerge and Threaten Democracy in Latin America. Chapel Hill: University of North Carolina Press. 
McCary, John A. (2009) The Anbar Awakening: An Alliance of Incentives. The Washington Quarterly 32(1): 43-59.

McClintock, Michael. (1992) Instruments of Statecraft: U.S. Guerrilla Warfare, Counterinsurgency, and Counterterrorism, 1940 -1990. New York: Pantheon Books.

Mitchell, Neil. (2004) Agents of Atrocity: Leaders, Followers and Human Rights Violations in Civil Wars. New York: Palgrave Macmillan.

Mitchell, Neil, Sabine Carey and Christopher Butler. (2014) The Impact of Pro-Government Militias on Human Rights Violations. International Interactions 40(5): 812-836.

Montgomery, Colonel Gary and Chief Warrant Officer Timothy McWilliams, eds. (2009) Al Anbar Awakening: Iraqi Perspectives. (Volume II) Quantico, Virginia: Marine Corps University Press. < $\underline{\text { http://www.hqmc.marines.mil/Portals/61/Docs/Al- }}$ AnbarAwakeningVolII\%5B1\%5D.pdf $>$ (Accessed 24 February, 2013).

Peic, Goran. (2014) Civilian Defense Forces, State Capacity, and Government Victory in Counterinsurgency Wars. Studies in Conflict and Terrorism 37(2): 162-184.

Plümper, Thomas., Vera Troeger, and Philip Manow. (2005) Panel Data Analysis in Comparative Politics: Linking Method to Theory. European Journal of Political Research 44(2): 327-354.

Raleigh, Clionadh. (2012) Violence Against Civilians: A Disaggregated Analysis. International Interactions 38(4): 462-281.

Schneider, Gerald and Margit Bussmann. (2013) Accounting for the dynamics of one-sided violence Introducing KOSVED. Journal of Peace Research 50(5): 635-644. 
Schubiger, Livia. (2012) Dynamics of Resistance: Civil War Violence and Counterinsurgent Mobilization in Peru. Paper presented at the Conference on Paramilitaries, Militias, and Civil Defense Forces in Civil Wars. Yale University, New Haven, CT: October 19-20, 2012.

SIGIR. (2011) Sons of Iraq Program: Results are Uncertain and Financial Controls are Weak. Office of the Special Inspector General for Iraq Reconstruction (SIGIR). Report 11-010 (28 January). <http://www.sigir.mil/files/audits/11-010.pdf> (Accessed 10 March, 2013).

Smith, Niel and Sean Macfarland. (2008) Anbar Awakens: The Tipping Point. Military Review. (March-April): 41-52. < $\underline{\text { http://www.dtic.mil/cgi- }}$ bin/GetTRDoc?Location=U2\&doc=GetTRDoc.pdf\&AD=ADA486828 $>$ (Accessed 15 March, 2013).

Staniland, Paul. (2014) Networks of Rebellion: Explaining Insurgent Cohesion and Collapse. Ithaca: Cornell University Press.

Staniland, Paul. (2012) Between a Rock and a Hard Place: Insurgent Fratricide, Ethnic Defection, and the Rise of Pro-State Paramilitaries. Journal of Conflict Resolution 56(1): $16-40$.

Stanton, Jessica. (2015) Regulating Militias: Governments, Paramilitaries, and Civilian Targeting in Civil War. Journal of Conflict Resolution April (Online first): 1-25.

Thomson, Janice E. (1994) Mercenaries, Pirates, and Sovereigns. Princeton: Princeton University Press.

Tilly, Charles. (2003) Armed Force, Regimes, and Contention in Europe Since 1650. In Irregular Armed Forces and Their Role in Politics and State Formation, eds. Diane Davis and Anthony W. Pereira, 37-81. Cambridge: Cambridge University Press. 
Valentino, Benjamin, Paul Huth, and Dylan Balch-Lindsay. (2004) 'Draining the Sea': Mass Killing and Guerrilla Warfare. International Organization 58(2): 375-407.

Weinstein, Jeremy. (2007) Inside Rebellion: The Politics of Insurgent Violence. Cambridge: Cambridge University Press.

What Happened in Haditha? (2008) BBC News.

<http://news.bbc.co.uk/1/hi/world/middle_east/5033648.stm> (Accessed 2 February, 2015)

Wood, Reed M. Jacob D. Kathman, Stephen E. Gent. (2012) Armed Intervention and Civilian Victimization in Intrastate Conflicts. Journal of Peace Research 49(5): 647-660.

Wood, Reed M. (2010) Rebel Capability and Strategic Violence Against Civilians. Journal of Peace Research 47(5): 601-614.

Zahar, Marie-Joelle. (2000) Proteges, Clients, Cannon Fodder: Civilians in the Calculus of Militias. International Peacekeeping 7(4); 107-128. 